\title{
Traumatic Tension Pneumopericardium
} Travmatik Tansiyon Pnömoperikardiyum

\author{
Mahmut Tokur', Mehmet Ergin² \\ 'Department of Thoracic Surgery, Sütçü Imam University, Faculty of Medicine, Kahramanmaraș, Turkey \\ ${ }^{2}$ Department of Emergency, Meram Faculty of Medicine, Selçuk University, Konya, Turkey
}

\section{ABSTRACT}

Tension pneumopericardium is a rare and life threatening condition which results from either penetrating or blunt thorax trauma. A 44-year-old man, who fell from the fifth floor of a building, had major trauma that consisted with hemorrhagic shock, pneumothorax and pneumopericardium, retroperitoneal hemorrhage, pelvic and lower extremity fractures. Multiple costal fractures, sternal fracture, right hemopneumothorax, massive air in the pericardial sac and diffuse subcutaneous emphysema were reported in the chest computed tomography. Pneumopericardium is usually self-limited but can progress into tension pneumopericardium causing cardiac tamponade. The drainage of pneumothorax could be the initial procedure in case of pneumothorax associated with pneumopericardium. However, emergent pericardiocentesis can be required for patients with resistant hypotension. Emergency physicians should consider this rare entity for the differential diagnosis of thorax trauma with shock and be familiar with its treatment options.

Keywords: Cardiac tamponade, multiple trauma, pneumopericardium

Received: 04.09.2010 Accepted: 29.06.2011

\section{ÖZET}

Tansiyon pnömoperikardiyum nadir ve penetran veya künt toraks travması sonucu hayati tehdit edici bir durumdur. Kırk dört yașındaki erkek hasta bir binanın beșinci katından düșme sonucu hemorajik şok, pnömotoraks ve pnömoperikardiyum, retroperitoneal kanama, pelvik ve alt ekstremite kırıklarının olușturdug̃u majör travma tablosundaydı. Toraks bilgisayarlı tomografisinde çok sayıda kot kırıg̃ı, sternum kırı̃̃ı, sag̃ hemopnömotoraks, perikardiyal kese içinde masif hava görünümü ve cilt altı amfizem rapor edildi. Pnömoperikardiyum genellikle kendini sınırlayıcıdır ancak kardiyak tamponada neden olan tansiyon pnömoperikardiyuma ilerleyebilir. Pnömotoraksın eșlik ettig̃i pnömoperikardiyum vakaları için pnömotoraksın drenajı bașlangıç tedavisi olabilir. Ancak, dirençli hipotansiyonu olan hastalar için acil perikardiyosentez gerekebilir. Acil servis doktorları, şok ile beraber olan toraks travmasının ayırıcı tanısında bu nadir tanıyı düșünmeli ve tedavi seçeneklerini bilmelidir.

Anahtar Kelimeler: Kardiyak tamponad, multipl travma, pnömoperikardiyum

Geliş Tarihi: 04.09.2010 Kabul Tarihi: 29.06.2011

\section{Introduction}

Tension pneumopericardium is a rare and life threatening condition which may arise spontaneously or secondary to blunt, penetrating or iatrogenic trauma $(1,2)$. In the absence of a direct communication, it has been proposed that pulmonary interstitial air may track along the pulmonary perivascular sheaths from ruptured alveoli (the Macklin effect) or via a congenital pleuropericardial connection (2).

\section{Case Report}

A 44 year-old man was brought to our emergency service after falling from the fifth floor of a building. He was unconscious and had tachycardia and respiratory distress. His blood pressure could not be measured. Sternum deformity, crepitation over the sternum and right hemithorax, pelvic instability and blood at the urethral meatus were seen. Rapid fluid replacement and intubation were initiated at our emergency service. Multiple costal fractures, sternal fracture, right hemopneumothorax, massive air in the pericardial sac and diffuse subcutaneous emphysema were reported in the chest computed tomography (CCT) (Figure 1). He had major trauma that consisted of hemorrhagic shock, pneumothorax and pneumopericardium, retroperitoneal hemorrhage, pelvic and lower extremity fractures. Tube thoracostomy in the right hemithorax and pericardiotomy following 


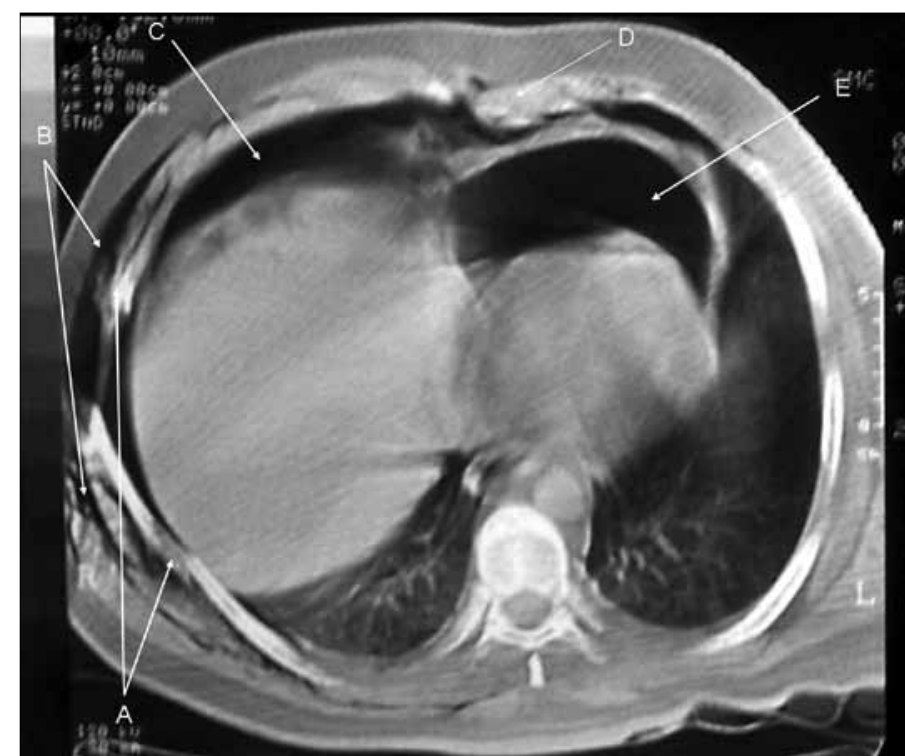

Figure 1. The chest computed tomography showing costal fracture $(A)$, diffuse subcutaneous emphysema (B), right pneumothorax (C), sternum fracture (D) and massive air in the pericardial sac (E)

left anterior thoracotomy were carried out in the operating room. Later, the patient's blood pressure and oxygen saturation improved. The pericardial window, reparation of lung parenchyma, fixation of costal and sternal fractures and insertion of drainage tubes were carried out during the operation.

\section{Discussion}

Pneumopericardium is usually self-limited but, rarely, can progress to tension pneumopericardium causing cardiac tamponade, as in our case $(1,2)$. This has been reported to occur in up to $37 \%$ of cases and is strongly associated with positive pressure ventilation (2). Tension pneumopericardium occurs when the air dissects along the adventitia of the pulmonary veins to compress the heart and decrease venous filling (3). This may result from a 'one way valve' mechanism within a pleuropericardial fistula, allowing the increased pleural pressures associated with positive pressure ventilation to be transmitted into the pericardial sac (2).

Pneumopericardium can be readily identified on plain films of the chest. The cephalic extent of air seen on chest X-ray is limited to the pericardial reflection onto the great vessels. If the diagnosis remains in question, a CCT scan identifies air within the pericardial space (1).

It has been suggested that consideration be given to prophylactic pericardial decompression of a simple pneumopericardium before commencing mechanical ventilation. By contrast, others advocate that the patient should simply be monitored (2). Di Filippo et al. (4) recommended that the drainage of the pneumothorax could be the initial procedure in case of pneumothorax associated with pneumopericardium. If, however, the patient has hypotension, an aggressive fluid resuscitation must be followed by emergent pericardiocentesis. Definitive treatment includes surgical pericardial decompression and pericardial window to provide drainage, as in our case (1).

\section{Conclusion}

Emergency physicians should keep this rare entity in mind for the differential diagnosis of thoracic trauma with shock and be familiar with its treatment options.

\section{Conflict of interest}

No conflict of interest was declared by the authors.

\section{References}

1. Polhill JL, Sing FR. Traumatic tension pneumopericardium. J Trauma 2009; 66: 1261. [CrossRef]

2. Macgoey $P$, Schamm M, Degiannis E. Tension pneumopericardium: case report. Ulus Travma Acil Cerrahi Derg 2010; 16: 477-9.

3. Hashmi S, Rogers SO. Tension pneumothorax with pnemopericardium. J Trauma 2003; 54: 1254. [CrossRef]

4. Di Filippo A, Batacchi S, Ciapetti M, Spina R, Peris A. Pneumopericardium after major trauma. J Trauma 2009; 66: 1260. [CrossRef] 